\title{
Religion: A Subset of Culture and an Expression of Spirituality
}

\author{
Inna Reddy Edara \\ Fu Jen Catholic University, Taiwan \\ Email: 065049@mail.fju.edu.tw
}

How to cite this paper: Edara, I. R. (2017). Religion: A Subset of Culture and an Expression of Spirituality. Advances in Anthropology, 7, 273-288.

https://doi.org/10.4236/aa.2017.74015

Received: July 18, 2017

Accepted: October 16, 2017

Published: October 19, 2017

Copyright $\odot 2017$ by author and Scientific Research Publishing Inc. This work is licensed under the Creative Commons Attribution International License (CC BY 4.0).

http://creativecommons.org/licenses/by/4.0/

\section{c) (i) Open Access}

\begin{abstract}
Cultures or cultural values, which are described as constructively created behaviors based on collective beliefs, are omnipresent at multiple levels in every human behavior and interaction, including in the sphere of religion. Scholars described religion as a cultural system of symbols, which establish powerful, pervasive, and long-lasting moods and motivations and naturalized conceptions of a general order of existence. Thus, religion is considered to be a part of culture and it acts as one among many forms of overtly expressing and experiencing spirituality that is inward, personal, subjective, transcendental, and unsystematic. In other words, cultural values are seen as a foundation to religiosity. Based on this assumption, this paper reviewed the literature to provide empirical evidence to the overt practice of religiosity that is embedded in particular cultural experiences and values as a form of expressing and experiencing the human universal of spirituality.
\end{abstract}

\section{Keywords}

Culture, Values, Religion, Spirituality

\section{Introduction}

Arnet (2008) indicated that much of the research in social sciences in the Western sphere focused on a philosophy of science emphasizing the fundamental Western values, which ignored the cultural contexts. Arnetthus suggested that a pertinent goal for social science research should be one that represents a demographic profile of humans in a broader and culturally diverse context, and place an emphasis on understanding human functioning in a cultural and ethnic context. Pedersen (1991) calls it a multicultural perspective, which "combines the extremes of universalism and relativism by explaining behavior both in terms of those culturally learned perspectives that are unique to a particular culture and 
in the search for common-ground universals that are shared across cultures" ( $\mathrm{p}$. 6).

In elaborating the rationale for cultural research and multicultural perspective, scholars maintain two broad views, of which one is a culture-free perspective and the other is a culture-embedded perspective (Pedrotti, Edwards, \& Lopez, 2009). The researchers with a culture-free perspective argue that there are universal attributes that transcend particular cultures and politics (Seligman \& Csikszenmihalyi, 2000), whereas those with a culture-embedded perspective argue that human functioning can only be viewed from within a cultural context (Constantine \& Sue, 2006).

Recently, many scholars have been endorsing the culturally embedded view of human affairs, and in particular, those operating from a multicultural framework argue that human functioning has to be understood in a given cultural context rather than in vacuum (Christopher, 2005; Constantine \& Sue, 2006; Pedrotti et al., 2009), because cultural values are omnipresent at multiple levels in every human behavior and interaction.

The complex human behavior or interaction can be explained by Kluckhohn and Murray's (1953) tripartite model, which describes human beings as simultaneously like all others, suggesting the universal dimension; like some others, suggesting the cultural or social dimension; and like no other, suggesting the uniqueness of each individual. There are many ways that human beings are like all other human beings. People are much more alike than they are different (Augsburger, 1986). This essential humanness is the fundamental basis for all empathy and all human relationships (Cooper-White, 2007). Yet, human beings are not isolated, but relational (Cooper-White, 2007), because they are shaped, formed, and patterned by the cultural community (Augsburger, 1986). People are not only born into cultures, but they also participate in and co-construct the cultures in which they are embedded (Cooper-White, 2007). Finally, every individual human being is unique (Cooper-White, 2007), with a distinctive developmental sequence, experience, life-style, and personality (Augsburger, 1986).

Augsburger (1986) indicated that many socio-psychological theories focus primarily on the unique and idiographic aspects and thus neglect the culturally defined expectations or universally accepted natural laws. Some other theories focus on the nomothetic aspects-common experiences or similar characteristics of all people-and thus neglect the individual peculiarities. Augsburger maintained that all three dimensions of the tripartite model should inform the culturally valid research and helping professions. He said that "only when the universal is clearly understood can the cultural be seen distinctly and the individual traits respected fully; only when the person is prized in her or his uniqueness can the cultural matrix be seen clearly and the universal frame be assessed accurately" (Augsburger, 1986: p. 49). Further, he said that "the universal unites us as humans, the cultural identifies us with significant persons, and the individual affirms our identity" (p. 50). 
Based on the aforementioned model, this paper reviewed the literature to validate the model on how the overt practice of religiosity that is embedded in particular cultural experiences and values is a form of expressing and experiencing the human universal aspect of spirituality.

\section{Spirituality: The Universal Dimension}

Before explaining spirituality as the universal dimension and given the recent polarizing developments in the understanding of religion and spirituality, it appears necessary to delineate these two concepts. Recent developments in the psychology of religion and spirituality have reified religion into a fixed system of ideological commitments with or without dynamic personal elements, and relegated spirituality to the personal dynamics and subjective experience of religion (Hill \& Pargament, 2003). Based on these developments, scholars proposed three broad approaches to understanding the meanings of spirituality and religion. The first approach is that spirituality and religion are seen as a single construct, in which spirituality and religion or religiosity are interchangeable (see Hill et al., 2000; Hill \& Pargament, 2003; Musick, Traphagan, Koenig, \& Larson, 2000; Zinnbauer \& Pargament, 2005). The second approach is polarization, in which religiosity represents an institutional, formal, doctrinal expression, and spirituality represents a personal, subjective, inward, and unsystematic expression (Hill \& Pargament, 2003; Moberg, 2002). The final approach is viewing them as related constructs, where religiosity and spirituality represent related rather than two independently polarized constructs (Hill et al., 2000). According to Zinnbauer and Pargament (2005), both spirituality and religiosity include a significant search for the sacred. This search for the sacred occurs in a larger religious context, one that may be traditional or nontraditional (Hill et al., 2000); nontraditional implying a search for the sacred in alternative spirituality practices, such as yoga, astrology, tarot, and horoscopes (Glendinning \& Bruce, 2006).

Based on the approaches and the tripartite model being considered here, spirituality and religion are seen as polarized constructs belonging to different dimensions. Religion is considered to be a part of culture and acts as one among many forms of overtly expressing and experiencing spirituality that is inward, personal, subjective, transcendental, and unsystematic.

As a separate construct from systematic and overt religion, spirituality is seen by many social scientists as an essential dimension of human life (Ortiz, Villereal, \& Engel, 2000), an ontologically existent phenomenon (Moberg, 2002), and an innate drive in humans to have a connection with a deeper source of wisdom (Jerry, 2003). Citing sociologist Sturzo who asserted that every person and all of society exist within a supernatural atmosphere, Moberg (2002) said that spirituality could be seen as an aspect of universal human experience.

Given this universal dimension to spirituality, scholars rendered spirituality various descriptions, some of which included the presence of a relationship with a Higher Power; the human response to God's call to a relationship with himself; 
the search for existential meaning; the way a person relates to the ultimate conditions of existence; a transcendent dimension within human experience; and a subjective experience of the sacred (Zinnbauer \& Pargament, 2005; Zinnbauer, Pargament, \& Scott, 1999). Spirituality is also defined as a search for the sacred (Pargament, 2007); the engagement with the sacred (Barry, Nelson, Davarya, \& Urry, 2010); an innate capacity and tendency to move towards connectedness and transcendence (Fukuyama \& Sevig, 1999); and as a subjective relationship to larger and transcendental realities (Piedmont, Ciarrocchi, Dy-Liacco, \& Williams, 2009).

Not only the descriptions of spirituality, but also the research on spirituality has been assuming that all people are spiritual beings and a normative value judgment of universal spirituality has been dominant in research on spirituality. For instance, a research study by Dy-Liacco and colleagues (2009) established the generalizability of spirituality as an aspect of universal human experience across different religious and psychological cultures by providing support for the hypothesis that spirituality has similar meanings and functions for Filipino Catholics as for American Protestants. A study by Piedmont and Leach (2002) has indicated that spirituality is a basic element of who we are as human beings and it represents a universal aspect of the individual that is recognizable among people of different faiths and cultures. In other words, human beings' desire to connect with some larger and sacred reality has been a constant force in various human societies over the centuries.

Regarding religion as a cultural tool to experiencing and expressing the innate and the universal spirituality, all the major religions in the world teach that spirituality represents a uniquely human and universal capacity that is present in all persons to engage in a personal relationship with a supreme transcendent reality. Moberg (2002) theorized that spirituality's central core universally characterizes all people, no matter how its specifics may have been defined, verbalized, adapted, and ritualized. For example, God is described in Hebrew, Christian, and Islamic traditions as a Personal Divine, theistic or theistic-relational in nature. The Hebrew tradition talks about a close and intimate covenant relationship of the Divine with people. The Christian tradition views a loving and personal relationship with God through the manifestation of Jesus as essential for wholeness. The central beliefs in Islamic tradition include the unity of God and all things (see Fukuyama \& Sevig, 1999; Richards, Keller, \& Smith, 2004).

In the Eastern traditions, God is described as the Impersonal Divine or non-dual in nature, with an emphasis on no separation of self from the Divine. For instance, a profound Hindu prayer "Aham Brahmasmi" translated into English as "I am Brahman or God," is a prayer of openness to one's consciousness so that the Transcendent presence within may emerge to assume the devotee's true identity as the self-centered ego diminishes. The Buddhist perspective encourages mindful awareness through which a person dissolves all illusions of separateness and gains insight into the impermanence of life (see Catoir, 1985; Fu- 
kuyama \& Sevig, 1999; Richards et al., 2004).

Thus, the essence of universal spirituality is a transcendent quality that cuts across cultures and infuses all of the core dimensions of religiosity and human functioning with meaning (Moberg, 2002). Moreover, there seems to be an empirical support with respect to the possible innateness of spirituality (D'Onofrio, Eaves, Murrelle, Maes, \& Spilka, 1999; Kendler, Gardner, \& Prescott, 1997; Miller, Weissman, Gur, \& Adams, 2001). Particularly, in a human being who is goal-oriented and intrinsically motivated (Emmons, Cheung, \& Tehrani, 1998), spirituality reflects an individual's innate orientation toward a larger transcendent reality (Piedmont, 1999). In fact, Baumeister (2002) and Stark (2001) construed spirituality as the highest level of motivation that arises out of an innate and unique human quality behind humankind's search for meaning in life, and they therefore argued that spirituality definesculture.

On the other hand, because spirituality is still a part of specific religious doctrinal and dogmatic formation, it raises the question of whether or not the universal appeal of spirituality is culturally determined (Nagai, 2007), and whether it is in many ways a multicultural issue (Oman \& Thoresen, 2005). In other words, the contexts in which spirituality is reflected are the religious practices that are heterogeneous, dynamic, and culture-specific (Chatters, 2000). For example, a study by Krause, Ingersoll-Dayton, Liang, and Sugisawa (1999) demonstrated the importance of cultural variability and offered evidence that religious service attendance may be less relevant to health in Japanese culture than in American culture. On the other hand, a study by Hood et al. (2001) demonstrated the significance of cultural similarity by offering evidence of similar factorial patterns underlying mystical experiences in Christian and Islamic cultures. These studies suggest that religion, although one form of experiencing and expressing the universal spirituality, is heterogeneous and culture-specific, suggesting that religion is an aspect of a larger cultural framework of the peoples.

\section{Religion: A Subset of Culture}

Broadly speaking, since culture permeates the whole social fabric of people, it can be described as a way of life (Smith, Richards, \& Granley, 2004), and it is an important area of interaction and understanding among people (Gasimova, 2008; Miller \& Kelley, 2005). Cultures can be learned and acquired, because they consist of ideas, attitudes, values, beliefs, and philosophies of life shaped by the upbringing of the people in specific cultural contexts (Fukuyama \& Sevig, 1999). In other words, cultures reflect the patterns of thinking, feeling, acting and reacting, values and other meaningful systems for people. Culture is usually transmitted through the principle of cultural succession (Gasimova, 2008) and collective programming of the mind (Hofstede, 1980), which distinguish members of one group from another with a broad tendency to prefer certain states of affairs and values to others. Thus, culture is described as constructively created behaviors based on collective beliefs (Nagai, 2007). 
Defining culture in broader terms helps us to assume that religious culture is asubset of culture at large, with meanings that are although overlapping with yet distinguishable from other subsets such as educational culture, entertainment culture, economic culture, political culture or media culture. In this line of thinking, Geertz (1973) described religion as a cultural system of symbols, which establish powerful, pervasive, and long-lasting moods and motivations and naturalize conceptions of a general order of existence (p. 91). In the recent past, Zinnbauer and Pargament (2005) compiled the past and present definitions of religion or religiosity used by various researchers. Some of these definitions included: a system of beliefs in a divine power and practices of worship directed towards such a power; the inner experience of an individual when she or he senses a Beyond and active attempts to harmonize his or her life with this Beyond; a community of faithful people who follow certain teachings that enhance their search for the sacred.

The relation of culture to religiosity means that in spite of the universalism perspective on spirituality, people experience and express spirituality in diverse ways based on their social and cultural worldviews that are composed of attitudes, values, concepts, and philosophies of life. For example, the Kluckhohn model for worldviews provides a structure for understanding cultural values as a foundation to religiosity and as expressions of spirituality within a cultural context (Fukuyama \& Sevig, 1999; Fukuyama, Siahpoush, \& Sevig, 2005). The model includes five value dimensions: a) human nature, which can be seen as good or bad or mixed; b) relation of humans to nature, which is seen by different cultures where humans are subjugated by or in harmony with or have mastery over nature; c) activity orientation, which is viewed as doing or being or becoming; d) time orientation, which is the differential focus on the past or present or future; and e) relational, which emphasizes either individual or group.

These value dimensions provide a cultural framework in conceptualizing the religiosity and experiencing the spirituality of people of different cultures. For instance, the European is likely to hold a value system of mastery, doing, future orientation, and individualism that influences his or her understanding of religiosity and the experience of spirituality (Fukuyama \& Sevig, 1999). Epstein (1995) emphasized the value of experiential illusions in the Eastern traditions as opposed to the Western understanding of illusion as perceptional distortion of objective reality. Epstein further clarified his point by stressing the Buddhist principle that we are nothing but experience. In helping professions, for example in clinical practice, the experiential illusions of culture, religiosity, and psyche help us "being" in therapy rather than overemphasizing "doing", a Westernvalue that rushes to eliminate symptoms. The understanding through cultural framework also helps us to be aware of differences between the Western practice of "working-through" and the Eastern practice of "working-toward" (Epstein, 1995).

One of the ego functions that is valued more in the Western cultures and less 
in the Eastern cultures is the mastery of nature (Yi, 1995). The Eastern cultures encourage being contained within nature, while the Western cultures seem to encourage the mastery over nature (Nagai, 2007; Yi, 1995). Further, some of the Eastern cultures influenced by Buddhist thought emphasize being in the present moment; Indian yoga traditions view doing as a means to higher spiritual consciousness; and people who embrace New Age religious values focus on the becoming aspect of religious development. The differences are further defined by the Western cultural perspective of God or Higher Power as a Personal Divine and theistic-relational in nature, whereas the Eastern traditions view God as Impersonal Divine and non-dual in nature (Fukuyama et al., 2005).

In reference to the relational aspect, Eastern cultures use more autoplastic adaptations in order to accept the demands of others in society (Nagai, 2007). In this same regard, the defense mechanism of suppression is more commonly observed in the collectivist cultures in order to maintain harmony, whereas repression may be more commonly observed in the individualist cultures (Hsu, 1949; Nagai, 2007). Along the same line of thinking comes the Eastern concept of self that is viewed as a constellation of internal representations of relationships with others, thus leading to multiple self and object representations experienced as the extensions of families and communities (Tisdale, Key, \& Edwards, 1997). The concept of self in the individualist Western cultures is constrained by selfawareness, self-control and self-esteem, so much so that the Dalai Lama, who is said to embody the Asian culture and Eastern religion and spirituality, could not grasp the meaning of self-esteem (see Epstein, 1995: p. 177).

Thus, the Eastern self makes a healthy development by dependency on others and through the feeling of fusion, while the Western self develops through the process of separation (Okonogi, 2005). This contrast is illustrated by Nagai's (2007) comparison of the punishment for misbehavior in the Asian and Western cultures. Nagai said that punishment for misbehavior among the Asian cultures is banishment from the family, indicating separation from the primary objects, while children in the Western cultures are more opt to be grounded, indicating the restriction of autonomy and independence.

Moberg (2002) attributed the above variations in value systems to three different approaches: a) theological or dogmatic interpretations, b) anthropological understandings, and c) historical-contextual approaches. Understanding religion and spirituality from a cultural perspective falls under the anthropological interpretations and historical-contextual approaches. In other words, many of the variations in the expression of religiosity and the experience of spirituality flow from the aspects of cultural influences. That is, particular features of religiosity dwell upon the richness of certain cultural content. For example, the religiosity in the Eastern culture can be described as introverted that is primarily oriented toward the inner life of the human being, whereas in the Western culture it is described as extroverted. In other words, culture builds up a social mechanism that maintains the type of religiosity that is acceptable in a given cultural context (Gasimova, 2008). 


\subsection{Empirical Evidence}

As indicated earlier, culture is a way of life, consisting of differing worldviews, ideas, values, beliefs, and philosophies. Hence, it is no wonder that the researchers have been emphasizing that the study of people should be done in their cultural context, for it is rare for any individual to behave without responding to some aspect of culture (Pedersen, 1991). One of the cultural constructs that has been of a great interest to a wide range of researchers has been that of individualism-collectivism (Singelis, Triandis, Bhawuk, \& Gelfand, 1995). In the following paragraphs, this construct is briefly described and its relationship to religion and spirituality is explained by citing some of the empirical studies.

\subsection{Individualism-Collectivism}

Hofstede (1980) defined individualism as having emphasis on personal autonomy and self-fulfillment, and the basing of one's identity on one's personal accomplishments. Later research on individualism expanded it to include a focus on personal responsibility and freedom of choice (Sampson, 2001). Thus, individualism is a cultural worldview that centralizes the personal aspects of people (Oyserman, Coon, \& Kemmelmeier, 2002; Shulruf, Hattie, \& Dixon, 2007), and emphasizes "I" consciousness, autonomy, emotional independence, and individual initiative (Brewer \& Chen, 2007). On the other side, the core element of collectivism is the assumption that the groups bind and mutually obligate individuals (Oyserman et al., 2002); and that the individuals are interconnected and are embedded in interdependent social relationships (Brewer \& Chen, 2007). The collectivist societies are communal societies in which common goals and common values are centralized (Oyserman et al., 2002; Shulruf et al., 2007). People in the collectivist cultures stress "we" consciousness, emotional dependence, group solidarity, duties and obligations (Brewer \& Chen, 2007).

Hofstede (1980) conceptualized individualism-collectivism as bipolar opposites. A review of the literature highlighted that cultures are not pure and individualism-collectivism constructs are not unidimensional, and therefore, it was proposed to make the distinction between vertical and horizontal individualism and collectivism (Singelis et al., 1995; Sivadas, Bruvold, \& Nelson, 2008; Triandis \& Gelfand, 1998). The horizontal aspect emphasizes equality and the vertical emphasizes hierarchy. According to the horizontal patterns, one's understanding of self is more or less like other selves; in contrast, in the vertical patterns, one's self is different from other selves (Chiou, 2001; Singelis et al., 1995; Triandis \& Gelfand, 1998). Combinations of relative emphases with individualism-collectivism produce four distinct patterns: horizontal collectivism (HC), vertical collectivism (VC), horizontal individualism (HI), and vertical individualism (VI) (Chiou, 2001; Singelis et al., 1995).

Horizontal collectivism (HC) implies valuing social relations with equals (Schimmack, Oishi, \& Diener, 2002). Well-being of in-groups is important for HCs, but there is no feeling of being subordinate to their in-groups or authority 
(Chiou, 2001). HC also emphasizes common goals and interdependence (Triandis \& Gelfand, 1998). Vertical collectivism (VC) implies valuing social relations with superiors including parents (Schimmack et al., 2002). Vertical collectivists submit to the structures of their in-groups and are willing to sacrifice their personal identities and goals for the in-group stability (Chiou, 2001). Horizontal individualism (HI) reflects a person's tendency to have an independent self-concept, to value uniqueness (Schimmack et al., 2002), and to be distinct from groups (Triandis \& Gelfand, 1998). Horizontal individualists seek individuality rather than distinctiveness (Chiou, 2001). Finally, vertical individualists (VC) stress the importance of competition (Chiou, 2001; Schimmack et al., 2002); are concerned with comparing themselves with others (Chiou, 2001); and want to acquire status (Triandis \& Gelfand, 1998).

These two cultural constructs with four distinct patterns categorize the largest concentrations of the population of the world, predominantly the individualist Europe and the collectivist Asia. Scholars assume that individualism is more prevalent in the industrialized Western societies than in more traditional and developing societies (Sampson, 2001). Research also suggested that the cultures of Western Europe, Canada, and some ethnic groups in the United States tend to be individualistic, whereas those of Africa, Asia, and Latin America tend to be collectivistic (Hofstede, 1980; Sivadas et al., 2008; Triandis, 1989). With regard to the four-fold typology of individualism-collectivism constructs, for example, Denmark represents the HI culture in which people consider it inappropriate to stand apart from their in-group by aiming at status or achievements (Sivadas et al., 2008; Triandis, 2004). The United States represents the VI dimension in which people want to be the best and strive for achievement (Sivadas et al., 2008). India is a VC culture, probably influenced by its historically embedded caste system in the society. Japan also represents a VC culture (Singelis et al., 1995). Israel and China represent the HC culture (Sivadas et al., 2008).

\subsection{Religion/Spirituality and Individualism-Collectivism}

Various studies have indicated the significant relation between religion/spirituality and the cultural constructs. For example, a study by Dy-Liacco et al. (2009) with 654 Filipino samples indicated a significant correlation between faith measured by Faith Maturity Scale that is crossed with vertical and horizontal dimensions, religion measured by the Religiosity Index, and a single dimension of Individualism-Collectivism scale. The estimates of correlations with the cultural dimension of individualism indicated moderate significant negative correlations with vertical faith, horizontal faith, and religiosity. Multiple regression and incremental validity analyses in the Dy-Liacco and colleagues' research indicated that faith and religion were still significant after controlling for personality in predicting the cultural constructs and explained $4 \%$ of the incremental variance. Other studies by Dy-Liacco, Kennedy, Parker, \& Piedmont (2005) with 261 Filipino subjects and by Piedmont et al. (2009) in a study with 467 college students from a 
Midwestern state university in the United States who were predominantly Catholic, also reported significant correlations between spiritual transcendence, religious sentiments, and a unidimensional measure of individualism-collectivism, with correlation estimates ranging from small to moderate values in magnitude.

In contrast to the above studies, which were mainly based on the Christian samples from the United States and the Philippines, Cukur, de Guzman, \& Carlo (2004) examined the relationships among subjective religiosity and individualismcollectivism in 475 college students in Turkey, the United States, and the Philippines. They found that greater religiosity was related to greater horizontal collectivism and vertical collectivism in all three countries, with the average correlations ranging from 0.24 for horizontal collectivism to 0.33 for vertical collectivism. Turkey had the highest estimate of correlation ( 0.41$)$ between religiosity and vertical collectivism and the Philippines had the strongest correlation (0.40) between religiosity and horizontal collectivism. Horizontal individualism was insignificant for the participants in all three countries. The analyses by Cukur et al. (2004) also revealed that for vertical individualism, the American participants and the Turkish participants scored higher than the Filipinos. On vertical collectivism, the Philippine participants scored higher than the Turkish and the American participants.

The above results were also supported by the measurement of values and their relation to individualism-collectivism (Cukur et al., 2004; Oishi, Schimmack, Diener, \& Suh, 1998). For example, collectivism (Cukur et al., 2004) and vertical collectivism (Oishi et al., 1998) were significantly and positively correlated with tradition and conformity, which are also values of people high in religiosity. Vertical individualism was negatively correlated with the value of universalism (Dy-Liacco et al., 2005; Oishi et al., 1998; Piedmont et al., 2009).

Further, Cohen and Hill (2007) provided a systematic evidence for differing religious collectivistic and individualistic identity and motivation among three religious cultural groups (Catholics, Jews, and Protestants) in the United States and thus proposed the theory that religious cultures vary in the individualistic and collectivistic aspects of religiousness and spirituality. They considered the individualistic religious identity and motivation as emphasizing the individual feelings, faith and personal relationship with God, and the collectivistic religious identity and motivation as emphasizing the social integration, ritual, and tradition.

Cohen and Hill's (2007) research results produced an evidence that differences in religious groups can be understood as differences in culture, and that groups of people who share religious identity could be meaningfully viewed as sharing different cultural models. Their results evidenced that the American Jews and Catholics resonated more with the collectivistic aspects of religion and spirituality than do Protestants. In several studies, using quite different measures, Cohen and Hill showed that the religious and spiritual identities, motivations, and experiences of Catholics and Jews are more socially and collectivist 
oriented than those of Protestants who are more religiously individualistic oriented.

In contrast to Cohen and Rozin's (2001) research that found that the American Jews and Protestants did not differ in the independent/interdependent selfconstrual scales, indicating that perhaps Jews and Catholics are more community oriented only in the domains of religion or spirituality (Cohen \& Hill, 2007). Thus, Cohen and Hill proposed that the religious identity and motivation must be understood within a cultural framework, and that religious group differences must be conceptualized as cultural differences. Under this perspective, Cohen and Hill advocated to view religions as subcultures (such as viewing Protestantism as a subculture in America).

Like in Cohen and Hill's (2007) work that focused on three religious groups (Catholics, Jews, and Protestants) in the United States, Edara's (2012) study also compared various religious groups (Christian, Catholic, Hindu, Buddhist, Jewish) in the United States and found significant differences on the selected religious and cultural measures. For example, Catholics had the higher mean scores on religious motivation, followed by Christians and Jews. Also, Catholics had the highest mean scores on spirituality, followed by Jews and Christians. Buddhists were high on individualism and Catholics were high on collectivism. These results once again suggest to view religions as subcultures of a broad national culture.

\section{Conclusion}

Cultures can be described as constructively created behaviors based on the collective beliefs that reflect the patterns of thinking, feeling, acting and reacting, values and other meaningful systems for people, thus distinguishing one group of people from another with a broad tendency to prefer certain states of affairs and values to others. These beliefs and values are usually transmitted through the principle of cultural succession and collective programming of the mind.

Therefore, it is necessary to understand the humans and their systems in a cultural and ethnic context that requires a multicultural or culture-embedded perspective, which attempts to combine the elements of universalism and relativism by explaining behavior and values both in terms of the culturally learned perspectives that are unique to a particular culture and the search for commonground universals that are shared across cultures.

Defining the culture in such broader terms and understanding the humans in a cultural context helps us to assume that religious culture is a subset of culture at large, with meanings that are although overlapping with yet distinguishable from other subsets such as educational culture, entertainment culture or economic culture. Hence, along this line of thought, religion can be described as a system of collective beliefs in a divine power and practices of worship directed towards such a power. Religion as a cultural system of symbols and values assists in establishing the communal, pervasive, and long-lasting motivations and be- 
haviors in expressing one's innate desire for a connection with a transcendental reality.

Therefore, many of the variations in the expression of religiosity and the experience of spirituality flow from the aspects of cultural influences. That is, particular features of religiosity dwell upon the richness, values, and beliefs of certain cultural content. In other words, culture builds up a social mechanism that maintains the type of religiosity that is acceptable to a group of people and can be collectively practiced in a given cultural context, thus making religion a subset of culture.

\section{References}

Arnet, J. J. (2008). The Neglected 95\%: Why American Psychology Needs to Become Less American. American Psychologist, 60, 602-614. https://doi.org/10.1037/0003-066X.63.7.602

Augsburger, D. W. (1986). Pastoral Counseling across Cultures. Philadelphia, PA: The Westminster Press.

Barry, C. M., Nelson, L., Davarya, S., \& Urry, S. (2010). Religiosity and Spirituality during the Transition to Adulthood. International Journal of Behavioral Development, 34, 311-324. https://doi.org/10.1177/0165025409350964

Baumeister, R. F. (2002). Religion and Psychology: Introduction to the Special Issue. Psychological Inquiry, 13, 165-167. https://doi.org/10.1207/S15327965PLI1303_01

Brewer, M. B., \& Chen, Y. R. (2007). Where (Who) Are Collectives in Collectivism? Toward Conceptual Clarification of Individualism and Collectivism. Psychological Review, 114, 133-151. https://doi.org/10.1037/0033-295X.114.1.133

Catoir, J. T. (1985). World Religions: Beliefs behind Today's Headlines. New York, NY: The Christophers.

Chatters, L. M. (2000). Religion and Health: Public Health Research and Practice. Annual Review of Public Health, 21, 335-367. https://doi.org/10.1146/annurev.publhealth.21.1.335

Chiou, J. S. (2001). Horizontal and Vertical Individualism and Collectivism among College Students in the United States, Taiwan, and Argentina. The Journal of Social Psychology, 141, 667-678. https://doi.org/10.1080/00224540109600580

Christopher, J. C. (2005). Situating Positive Psychology. Naming and Nurturing. The e-Newsletter of the Positive Psychology Section of the American Psychological Association's Counseling Psychology Division, 17, 3-4.

Cohen, A. B., \& Hill, P. C. (2007). Religion as Culture: Religious Individualism and Collectivism among American Catholics, Jews, and Protestants. Journal of Personality, 75, 710-742. https://doi.org/10.1111/j.1467-6494.2007.00454.x

Cohen, A. B., \& Rozin, P. (2001). Religion and the Morality of Mentality. Journal of Personality \& Social Psychology, 81, 697-710. https://doi.org/10.1037/0022-3514.81.4.697

Constantine, M., \& Sue, D. W. (2006). Factors Contributing to Optimal Human Functioning of People of Color in the United States. The Counseling Psychologist, 34, 228-244. https://doi.org/10.1177/0011000005281318

Cooper-White, P. (2007). Many Voices: Pastoral Psychotherapy in Relational and Theological Perspective. Minneapolis, MN: Fortress Press.

Cukur, C. S., de Guzman, M. R. T., \& Carlo, G. (2004). Religiosity, Values, and Horizon- 
tal and Vertical Individualism-Collectivism: A Study of Turkey, the United States, and the Philippines. Journal of Social Psychology, 144, 613-634.

https://doi.org/10.3200/SOCP.144.6.613-634

D’Onofrio, B. M., Eaves, L. J., Murrelle, L., Maes, H. H., \& Spilka, B. (1999). Understanding Biological and Social Influences on Religious Affiliation, Attitudes, and Behaviors: A Behavior Genetic Perspective. Journal of Personality, 67, 953-984. https://doi.org/10.1111/1467-6494.00079

Dy-Liacco, G. S., Kennedy, C., Parker, D., \& Piedmont, R. L. (2005). Spiritual Transcendence as an Unmediated Causal Predictor of Psychological Growth and Worldview among Filipinos. Research in the Social Scientific Study of Religion, 16, 261-285. http://www.brill.nl/publications/research-social-scientific-study-religion

Dy-Liacco, G. S., Piedmont, R. L., Murray-Swank, N. A., Rodgerson, T. E., \& Sherman, M. F. (2009). Spirituality and Religiosity as Cross-Cultural Aspects of Human Experience. Psychology of Religion and Spirituality, 1, 35-52. https://doi.org/10.1037/a0014937

Edara, I. R. (2012). Role of Ethnicity and Culture in Spirituality's Influence on Subjective Well-Being and Forgiveness over and above Personality: Comparison of European Americans, Asian Indian Americans, and Chinese Americans. Unpublished Doctoral Dissertation, Columbia, MD: Loyola University Maryland.

Emmons, R. A., Cheung, C., \& Tehrani, K. (1998). Assessing Spirituality through Personal Goals: Implications for Research on Religion and Subjective Well-Being. Social Indicators Research, 45, 391-422. https://doi.org/10.1023/A:1006926720976

Epstein, M. (1995). Thoughts without a Thinker: Psychotherapy from a Buddhist Perspective. New York, NY: MJF Books.

Fukuyama, M. A., \& Sevig, T. D. (1999). Integrating Spirituality into Multicultural Counseling. Thousand Oaks, CA: Sage Publications.

Fukuyama, M. A., Siahpoush, F., \& Sevig, T. D. (2005). Religion and Spirituality in a Cultural Context. In C. S. Cashwell, \& J. S. Young (Eds.), Integrating Spirituality and Religion into Counseling: A Guide to Competent Practice (pp. 123-142). Alexandria, VA: American Counseling Association.

Gasimova, G. (2008). Philosophical Aspects of Cultural Relationships. Journal of Russian and East European Psychology, 46, 5-12. https://doi.org/10.2753/RPO1061-0405460101

Geertz, C. (1973). The Interpretation of Cultures. New York, NY: Basic Books.

Glendinning, T., \& Bruce, S. (2006). New Ways of Believing or Belonging: Is Religion Giving Way to Spirituality? The British Journal of Sociology, 57, 399-414. https://doi.org/10.1111/j.1468-4446.2006.00117.x

Hill, P. C., \& Pargament, K. I. (2003). Advances in the Conceptualization and Measurement of Religion and Spirituality: Implications for Physical and Mental Health Research. American Psychologist, 58, 64-74. https://doi.org/10.1037/0003-066X.58.1.64

Hill, P. C., Pargament, K. I., Hood, R. W. Jr., McCullough, M. E., Swyers, J. P., Larson, D. B., \& Zinnbauer, B. J. (2000). Conceptualizing Religion and Spirituality: Points of Commonality, Points of Departure. Journal for the Theory of Social Behaviour, 30, 51-77. https://doi.org/10.1111/1468-5914.00119

Hofstede, G. (1980). Culture's Consequences: International Differences in Work-Related Values. Beverly Hills, CA: Sage.

Hood, R. W., Ghorbani, N., Watson, P. J., Ghramaleki, A. F., Bing, M. N., Davison, Williamson, W. P. et al. (2001). Dimensions of the Mysticism Scale: Confirming the Three-Factor Structure in the United States and Iran. Journal for the Scientific Study of 
Religion, 40, 691-705. https://doi.org/10.1111/0021-8294.00085

Hsu, F. L. K. (1949). Suppression versus Repression: A Limited Psychological Interpretation of Four Cultures. Psychotherapy, 12, 223-242. https://doi.org/10.1080/00332747.1949.11022736

Jerry, P. A. (2003). Challenges in Transpersonal Diagnosis. The Journal of Transpersonal Psychology, 35, 43-59.

Kendler, K. S., Gardner, C. O., \& Prescott, C. A. (1997). Religion, Psychopathology, and Substance Use and Abuse: A Multimeasure, Genetic-Epidemiological Study. American Journal of Psychiatry, 154, 322-329. https://doi.org/10.1176/ajp.154.3.322

Kluckhohn, C., \& Murray, H. A. (1953). Personality Formation: The Determinants. In C. Kluckhohn, H. A. Murray, \& D. M. Schneider (Eds.), Personality in Nature, Society, and Culture (2nd ed., pp. 53-69). New York, NY: Alfred A. Knopf.

Krause, N, Ingersoll-Dayton, B., Liang, J., \& Sugisawa, H. (1999). Religion, Social Support, and Health among the Japanese Elderly. Journal of Health and Social Behavior, 40, 405-421. https://doi.org/10.2307/2676333

Miller, L., \& Kelley, B. S. (2005). Relationships of Religiosity and Spirituality with Mental Health and Psychopathology. In R. F. Paloutzian, \& C. L. Park (Eds.), Handbook of the Psychology of Religion and Spirituality (pp. 460-478). New York, NY: Guilford.

Miller, L., Weissman, M. M., Gur, M., \& Adams, P. (2001). Religiousness and Substance Use in Children of Opiate Addicts. Journal of Substance Abuse, 13, 323-326.

Moberg, D. O. (2002). Assessing and Measuring Spirituality: Confronting Dilemmas of Universal and Particular Evaluative Criteria. Journal of Adult Development, 9, 47-60. https://doi.org/10.1023/A:1013877201375

Musick, M. A., Traphagan, J. W., Koenig, H. G., \& Larson, D. B. (2000). Spirituality in Physical Health and Aging. Journal of Adult Development, 7, 73-86. https://doi.org/10.1023/A:1009523722920

Nagai, C. (2007). Culturally Based Spiritual Phenomena: Eastern and Western Theories and Practices. Psychoanalytic Social Work, 14, 1-22. https://doi.org/10.1300/J032v14n01_01

Oishi, S., Schimmack, U., Diener, E., \& Suh, M. (1998). The Measurement of Values and Individualism-Collectivism. Personality and Social Psychology Bulletin, 24, 1177-1189. https://doi.org/10.1177/01461672982411005

Okonogi, K. (2005). The Ajase Complex and Its Implications. In W. S. Tseng, S. C. Chang, \& M. Nishizono (Eds.), Asian Culture and Psychotherapy: Implications for East and West. Honolulu, HI: University of Hawaii Press.

Oman, D., \& Thoresen, C. E. (2005). Do Religion and Spirituality Influence Health? In R. F. Paloutzian, \& C. L. Park (Eds.), Handbook of the Psychology of Religion and Spirituality (pp. 435-459). New York, NY: Guilford.

Ortiz, L., Villereal, S., \& Engel, M. (2000). Culture and Spirituality. Social Thought, 19, 21-26. https://doi.org/10.1300/J131v19n04_02

Oyserman, D., Coon, H. M., \& Kemmelmeier, M. (2002). Rethinking Individualism and Collectivism: Evaluation of Theoretical Assumptions and Meta-Analyses. Psychological Bulletin, 128, 3-72. https://doi.org/10.1037/0033-2909.128.1.3

Pargament, K. I. (2007). Spiritually Integrated Psychotherapy: Understanding and Addressing the Sacred. New York, NY: Guilford.

Pedersen, P. B. (1991). Multiculturalism as a Generic Approach to Counseling. Journal of Counseling and Development, 70, 6-12. https://doi.org/10.1002/j.1556-6676.1991.tb01555.x 
Pedrotti, J. T., Edwards, L. M., \& Lopez, S. J. (2009). Positive Psychology within a Cultural Context. In S. J. Lopez, \& C. R. Snyder (Eds.), Oxford Handbook of Positive Psychology (2nd ed., pp. 49-57). New York, NY: Oxford University Press. https://doi.org/10.1093/oxfordhb/9780195187243.013.0006

Piedmont, R. L. (1999). Does Spirituality Represent the Sixth Factor of Personality? Spiritual Transcendence and the Five-Factor Model. Journal of Personality, 67, 985-1014. https://doi.org/10.1111/1467-6494.00080

Piedmont, R. L., \& Leach, M. M. (2002). Cross-Cultural Generalizability of the Spiritual Transcendence Scale in India: Spirituality as a Universal Aspect of Human Experience. American Behavioral Scientist, 45, 1888-1901. https://doi.org/10.1177/0002764202045012011

Piedmont, R. L., Ciarrocchi, J. W., Dy-Liacco, G. S., \& Williams, J. E. G. (2009). The Empirical and Conceptual Value of the Spiritual Transcendence and Religious Involvement Scales for Personality Research. Psychology of Religion and Spirituality, 1, 162-179. https://doi.org/10.1037/a0015883

Richards, P. S., Keller, R. R., \& Smith, T. B. (2004). Religious and Spiritual Diversity in Counseling and Psychotherapy. In T. B. Smith (Ed.), Practicing Multiculturalism: Affirming Diversity in Counseling and Psychology (pp. 276-293). Boston, MA: Allyn and Bacon.

Sampson, E. E. (2001). Reinterpreting Individualism and Collectivism: Their Religious Roots and Monologic versus Dialogic Person-Other Relationship. American Psychologist, 55, 1425-1432. https://doi.org/10.1037/0003-066X.55.12.1425

Schimmack, U., Oishi, S., \& Diener, E. (2002). Cultural Influences on the Relation between Pleasant Emotions and Unpleasant Emotions: Asian Dialectic Philosophies or Individualism-Collectivism? Cognition and Emotion, 16, 705-719. https://doi.org/10.1080/02699930143000590

Seligman, M. E. P., \& Csikszentmihalyi, M. (2000). Positive Psychology: An Introduction. American Psychologist, 55, 5-14. https://doi.org/10.1037/0003-066X.55.1.5

Shulruf, B., Hattie J., \& Dixon, R. (2007). Development of a New Measurement Tool for Individualism and Collectivism. Journal of Psychoeducational Assessment, 25, 385-401. https://doi.org/10.1177/0734282906298992

Singelis, T. M., Triandis, H., Bhawuk, D., \& Gelfand, M. J. (1995). Horizontal and Vertical Dimensions of Individualism and Collectivism: A Theoretical and Measurement Refinement. Cross-Cultural Research: The Journal of Comparative Social Science, 29, 240-275. https://doi.org/10.1177/106939719502900302

Sivadas, E., Bruvold, N. T., \& Nelson, M. R. (2008). A Reduced Version of the Horizontal and Vertical Individualism and Collectivism Scale: A Four-Country Assessment. Journal of Business Research, 61, 201-210.

Smith, T. B., Richards, P. S., \& Granley, H. M. (2004). Practicing Multiculturalism: An Introduction. In T. B. Smith (Ed.), Practicing Multiculturalism: Affirming Diversity in Counseling and Psychology (pp. 3-17). Boston, MA: Allyn and Bacon.

Stark, R. (2001). Gods, Rituals, and the Moral Order. Journal for the Scientific Study of Religion, 40, 619-636. https://doi.org/10.1111/0021-8294.00081

Tisdale, T. C., Key, T. I., \& Edwards, K. J. (1997). Impact of Treatment on God Image and Personal Adjustment, and Correlations of God Image to Personal Adjustment and Object Relations Development. Journal of Psychology and Theology, 52, 227-239. http://psycnet.apa.org/psycinfo/1997-06809-005

Triandis, H. C. (1989). The Self and Social Behavior in Differing Cultural Contexts. Psychological Review, 96, 506-520. https://doi.org/10.1037/0033-295X.96.3.506 
Triandis, H. C. (2004). The Many Dimensions of Culture. Academy of Management EXecutive, 18, 88-93. http://www.jstor.org/stable/4166039 https://doi.org/10.5465/AME.2004.12689599

Triandis, H. C., \& Gelfand, M. J. (1998). Converging Measurement of Horizontal and Vertical Individualism and Collectivism. Journal of Personality and Social Psychology, 74, 118-128. https://doi.org/10.1037/0022-3514.74.1.118

Yi, K. Y. (1995). Psychoanalytic Psychotherapy with Asian Clients: Transference and Therapeutic Considerations. Psychotherapy, 32, 308-316. https://doi.org/10.1037/0033-3204.32.2.308

Zinnbauer, B. J., \& Pargament, K. I. (2005). Religiousness and Spirituality. In R. F. Paloutzian, \& C. L. Park (Eds.), Handbook of the Psychology of Religion and Spirituality (pp. 21-42). New York, NY: Guilford.

Zinnbauer, B. J., Pargament, K. I., \& Scott, A. B. (1999). The Emerging Meaning of Religiousness and Spirituality: Problems and Prospects. Journal of Personality, 67, 889-919. https://doi.org/10.1111/1467-6494.00077 